EGU Stephan Mueller Special Publication Series, 1, 3-16, 2002

(C) European Geosciences Union 2002

\title{
The implications of foreland basins for the causative tectonic loads
}

\author{
Z. Garfunkel ${ }^{1}$ and R. O. Greiling ${ }^{2}$ \\ ${ }^{1}$ Institute of Earth Sciences, Hebrew University, Jerusalem, Israel \\ ${ }^{2}$ Geological-Paleontological Institute, Ruprecht-Karls-Universität, Heidelberg, Germany
}

Received: 2 April 2001 - Revised: 10 September 2001 - Accepted: 26 September 2001

\begin{abstract}
The geometry and development of foreland basins, being controlled primarily by flexure in front of advancing orogenic wedges, contain information about these causative loads. Modeling of the flexure allows estimating the relations between basin width and depth and the taper angle of the orogenic wedges. These relations allow constraining the advance of tectonic wedges and their taper angle based on the onlap of the basin fill and facies migration and on the thickness of the basin fill.

Application of this approach to the Alps and the Acadian orogen of New England illustrates how the record of the associated foreland basins can be used to constrain the history of orogenic wedges and their taper angle. The first case also allows to test this approach, while the second case demonstrates its application to a deeply eroded orogen. In these examples the basin records reveal that the orogenic wedges continued to advance and down-flex the foreland well after the exposed levels of these wedges experienced peak metamorphism and deformation. The modeling also shows that during these late stages of loading of the foreland the orogenic wedges maintained or even increased their taper angles, even though they were much eroded. As erosion tends to reduce the loads, it follows that concurrent modification of the deeper parts of the wedges must have taken place and compensated for the reduction of the load by erosion. Such inferences regarding the history of orogenic wedges, which can be deduced from the flexural interpretation of foreland basins, may be difficult to obtain otherwise, especially when the structure that existed during basin formation was much obliterated by erosion and modified by subsequent deformation. This shows that integration of the insights that foreland basins provide regarding tectonic loads with information obtained from the interior of these loads can improve the understanding of the evolution of mountain chains.
\end{abstract}

Correspondence to: Z. Garfunkel (zvi_garf@cc.huji.ac.il)

\section{Introduction}

Foreland basins are generally accepted to express downflexing of the lithosphere in front of tectonic loads (Price, 1973; Beaumont, 1981; Jordan, 1981; Karner and Watts, 1983; Lyon-Caen and Molnar, 1985; Stockmal et al., 1986; Flemings and Jordan, 1989; Sinclair et al., 1991; Watts, 1992). Therefore the evolution of such basins should be tightly linked to, and contain significant information about, the evolution of the causative loads. This information can provide insights into the development of mountain belts that may be otherwise difficult to obtain, especially when much erosion or subsequent deformation obliterated the situation that existed during basin formation.

The relations between the histories of foreland basins and the adjacent mountain belts were studied from various points of view (e.g. Karner and Watts, 1983; Lyon-Caen and Molnar, 1985; Stockmal et al., 1987; Flemings and Jordan, 1989; Sinclair et al., 1991; Sinclair and Allen, 1992; Schlunegger et al., 1997a, b). In this work we use simple mechanical modeling of distributed two-dimensional loads as a basis for exploring how major basin properties, e.g. width, depth, and migration, are related to the gross geometric features of the adjacent orogenic loads during basin development. We focus on large-scale basin features that express the dominant flexural effects, though a more detailed analysis should also consider other factors that influence basin development. We then examine from this point of view two examples - the Cenozoic Molasse basin in front of the Alps and the Devonian foredeep in front of the north-central Appalachians - in order to illustrate the use of the foreland record to constrain the development of adjoining orogenic edifices. The insights into the orogenic history that are so obtained supplement the information that can be obtained from the orogenic edifices themselves. 


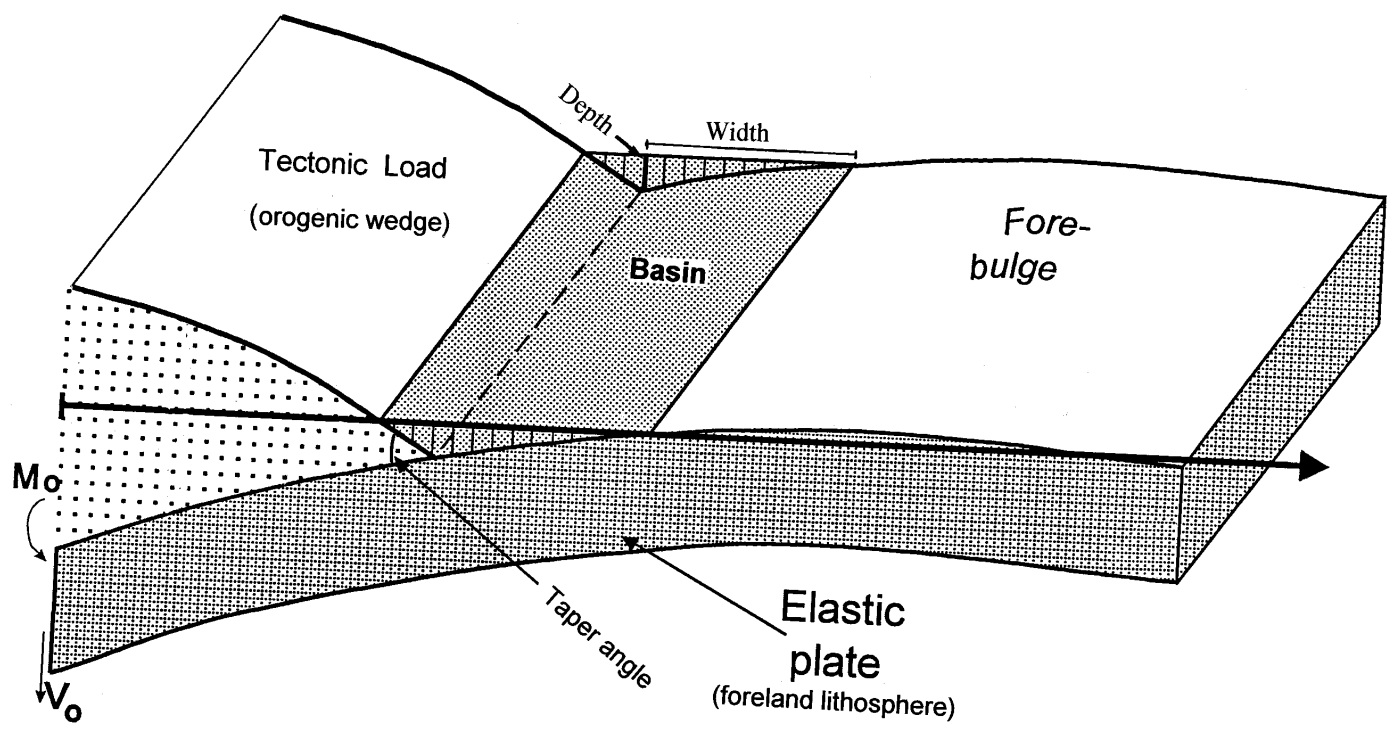

Fig. 1. Formation of a flexural basin and a forebulge in front of a tectonic load. The deflection at any point depends on the properties of the bent plate, the size and shape of the load and on bending moment $\left(\mathrm{M}_{0}\right)$ and a force $\left(\mathrm{V}_{0}\right)$ applied to the edge of elastic plate. See text for discussion.

\section{Modeling Basins}

In order to link the development of foreland basins and the causative tectonic loads the quantitative relations between their features need to be known. These relations were much studied before, so here only some points relevant for the present discussion are briefly summarized. Many studies (e.g. Jordan, 1981; Karner and Watts, 1983; Lyon-Caen and Molnar, 1985; Watts, 1992) show that the properties of foreland basins can be described by treating the underlying lithosphere as a thin elastic plate that overlies a viscous substratum and is flexed during the emplacement of orogenic loads. In reality the lithosphere has a more complicated rheology (Burov and Diament, 1995) but often its overall behavior can still be described as elastic, though other rheologies were also suggested (e.g. visco-elastic: Beaumont, 1981). Here we follow the common practice of using an elastic rheology as an adequate description, which allows to apply the theory of bending of thin plates (Hetenyi, 1946; Nadai, 1963; Turcotte and Schubert, 1982). In applying this physical description it is often useful to approximate foreland basin-orogen systems as having a two-dimensional geometry (Fig. 1). This allows to focus on the significant across-strike variations that dominate the flexure, while ignoring the less important influence of gradual along-strike variations. Ideally 3-D models should be used, but they are difficult to apply to ancient orogens where erosion and later deformation hinder detailed reconstruction of the loads that existed when foreland basins formed.

The flexure produced by distributed two-dimensional loads is obtained following Hetenyi (1946) and Nadai (1963) by treating finite loads as consisting of numerous elementary loads concentrated along strike-parallel lines. The total flexure is obtained by summing (integrating) the effects of these elementary concentrated loads, as detailed in the Appendix. The deflection produced by a concentrated linear load depends on its magnitude and on a parameter $\alpha$ with dimensions of length, the flexural parameter (see Appendix), whose value varies from less than $40 \mathrm{~km}$ for young and hot lithosphere to more than $100 \mathrm{~km}$ for old and cold lithosphere (Watts, 1992). The deflection varies in an oscillatory manner, its amplitude decreasing exponentially with distance from the load. The relations given in the Appendix show that when a line load is placed on a semi-infinite plate parallel to its edge the deflection decreases to zero at a distance varying between $1.57 \alpha$ to $2.35 \alpha$ from the load, depending on the distance of the load from the plate edge. Still further away from the load a low bulge forms, its width being $\alpha \pi$, while still further away the (oscillatory) deflection is very small. The deflection caused by forces and bending moments applied along the edge of the semi-infinite plate also decays exponentially with distance, the decay being governed by $\alpha$. Therefore the external parts of the orogenic loads, about $\alpha-1.5 \alpha$ wide, as well as the basin fill itself have a dominant effect on the geometry of the flexure of the foreland. Examination of many loads having a variety of shapes shows that the frontal $150 \mathrm{~km}$ of the loads govern the flexure of the foreland, whereas more internal parts of the loads have a small influence (Garfunkel and Greiling, 1996). The latter can be described as produced by a bending moment and a force acting on the supporting plate along a strike-parallel line under the internal part of the load.

Based on these considerations we explore how the width, depth and shape of foreland basins depend on the crosssection of the causative tectonic loads and on the mechanical properties of the lithosphere. The common shape of tectonic loads is that of a triangular wedge, which is the expected shape of homogeneous loads that attain a critical taper angle 
(Davis et al., 1983; Dahlen, 1990). Such loads always produce frontal depressions with approximately triangular cross sections, whose deepest point is situated next to the tip of the loads (Fig. 1). Figure 2 shows how the width and maximum depth of depressions (cf. Fig. 1) in front of $150 \mathrm{~km}$ wide triangular loads depend on the taper angle of the load and on the flexural parameter $\alpha$ when the basin-fill extends to the original level of the down-flexed foreland. Note that here basin width refers to the depression in front of the wedge, i.e. excluding the part of the depression that extends above the load tip (the wedge-top basin of DeCelles and Giles, 1996). Maximum basin depth increases with the taper angle for a constant $\alpha$, while for a given taper angle it increases with $\alpha$, because when $\alpha$ increases more internal and bulkier parts of the load contribute to the flexure in front of the load. On the other hand, for a given level of filling basin width is insensitive to the taper angle of the load. The basin width and maximum depth also depend on the density of the fill and on the level it reaches. Water-filled basins are 20\%-30\% narrower and 15$25 \%$ shallower than sediment-filled basins, and basins filled to above the original level of the foreland will be wider and somewhat deeper than shown. Detailed modeling should thus consider the factors controlling the filling of basins (Flemings and Jordan, 1989; Jordan and Flemings, 1991) as well as other factors, e.g. intraplate stresses (Cloetingh, 1988) that may modify basin geometry. However, since here we consider only large-scale features, we use the relations shown in Fig. 2, recognizing that these are first approximations only.

Another factor to be considered is the strong deformation of the load tips. This causes the frontal parts of the loads to have somewhat blunt and variable cross sections rather than the perfectly triangular shape used in our models. Modeling shows that in such cases the parts of the basin that extend above the load tips (the wedge-top area of DeCelles and Giles, 1996) are much reduced because the deformed edges of the loads occupy much of the internal part of the flexural depression (Garfunkel and Greiling, 1996). However, the width and depth of the depression in front of the load are quite similar to those produced by triangular loads (which are shown in Fig. 2). Thus, using the simple geometry allows avoiding the consideration of tip geometry that is not well constrained and still model large-scale basin features.

\section{The evolution of foreland basins}

The evolution of foreland basins was examined in many works (e.g. Jordan, 1981; Lyon-Caen and Molnar, 1985; Stockmal et al., 1986, 1987; Flemings and Jordan, 1989; Sinclair et al., 1991; Sinclair and Allen, 1992). Here we only discuss basin evolution from the point of view of the relations shown in Fig. 2. By themselves the models depict just particular states, but consideration of a succession of states allows using the models to describe the temporal evolution of flexure. This allows to utilize basin evolution for estimating the taper angle of the causative tectonic load and its advance,
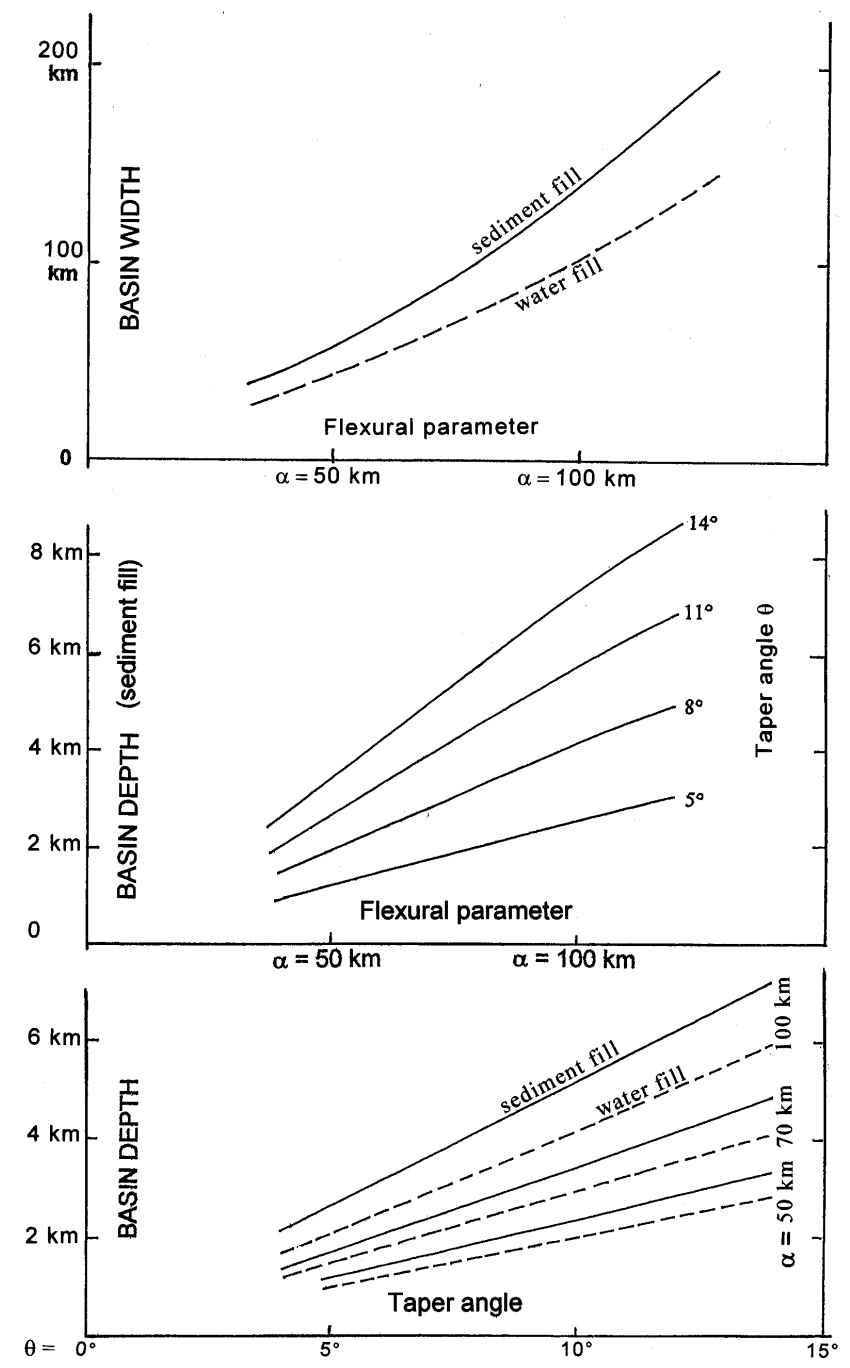

Fig. 2. Relations between width and depth of foreland basins (defined in Fig. 1) and the flexural parameter $\alpha$ and the taper angle $\theta$. The causative load is $150 \mathrm{~km}$ wide and has a triangular crosssection. The basin fill extends to the original level of the supporting plate.

and thereby to constrain the overall history of the adjacent orogen.

Many seismic reflection studies show that orogenic edifices consist of wedges that were pushed a few hundred kilometers over the foreland (Cook and Varsek, 1994; Roure et al., 1996; Hauk et al., 1998). Accordingly, the advance of orogenic loads is a major factor that accentuates the downflexing of the foreland. Simultaneously, the tectonic load may also thicken, e.g. by stacking of thrust sheets and/or by internal deformation and underplating, and this will also accentuate the flexure of the foreland. Continuing basin subsidence records the activity of either one or a combination of these processes.

The advance of orogenic wedges down-flexes successively more external portions of the foreland and causes the forebulge to migrate to more external parts of the foreland. 
A Advanicng constant-taper load

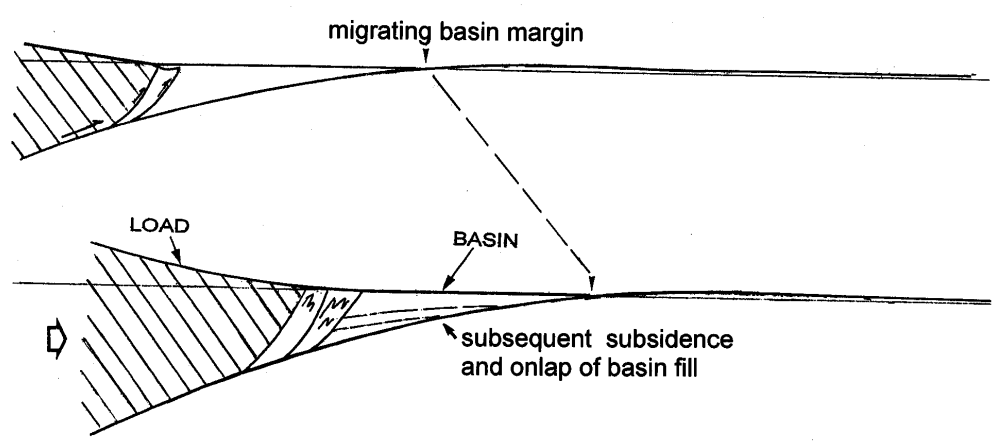

B Stationary load, taper angle increases
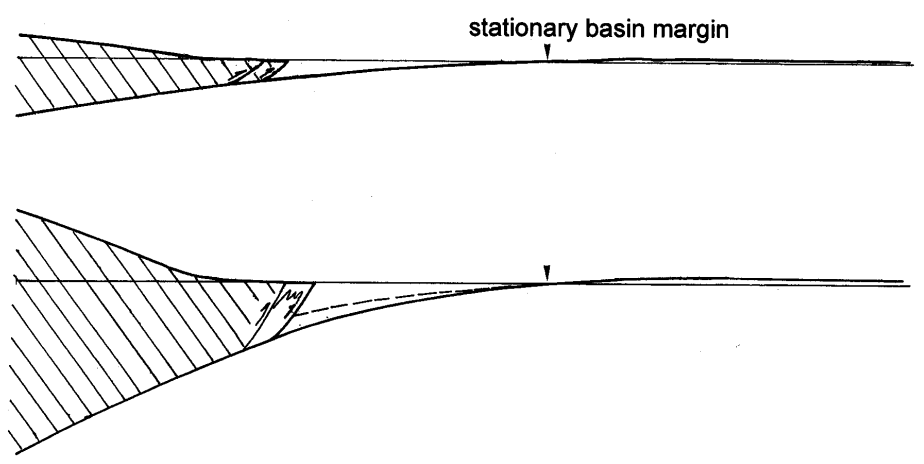

Fig. 3. Development of foreland basins. (a) - in front of advancing constanttaper loads. The flexural basin and the forebulge migrate to successively more external positions while maintaining their shape. As a result basin fill onlaps over the foreland. (b) - in front of a stationary load whose taper angle increases. The basin becomes deeper, but its width does not change.
Therefore, places originally far enough from an advancing load may be uplifted before subsiding as a result of the approach of the orogenic wedges. Points on the foreland will begin to subside when the load tip approaches them to within some $60 \mathrm{~km}$ to $150-200 \mathrm{~km}$, depending on $\alpha$ (Fig. 3), and their subsidence will be maximal when they are reached by the front of the tectonic wedge. As the flexural basin migrates, its fill will onlap over successively more external parts of the foreland. When the basin fill is maintained at a constant level then basin-width remains practically constant, so in such a situation the extent of onlap will be comparable to the displacement of the load and will provide a good approximation of its advance (Fig. 3a). When increased sediment supply raises the level of the basin floor, the onlap of its fill on the foreland will exceed the advance of the load.

The other process that can cause progressive subsidence of foreland basins is an increase in the taper angle of the load, which causes basin deepening even when the load does not advance (Fig. 3b). If at the same time the tectonic wedge maintains its triangular profile the basin width will not change, as it is practically independent of the taper angle. In this case the edge of the basin fill will not advance over the foreland while basin subsidence continues (unless sediment supply increases). An increase in the taper angle while the load continues to advance should accelerate basin subsidence compared to what is expected in front of an advancing constant-taper load, which may not be easy to decipher. However, continuing subsidence while the advance of the fill over foreland slows down and sediment supply does not decrease can be taken as evidence for an increase in the taper angle of the load.

In summary, the above considerations show that relations like those shown in Fig. 2 allow deriving several kinds of information from the features of foreland basins. Basin width (at any given moment) allows estimating the flexural parameter of the underlying lithosphere. Maximum basin depth can then constrain the taper angle of the causative load. The onlap of the basin fill over the foreland provides an estimate of the advance of the tectonic wedge. The relation between the histories of subsidence and onlap can reveal periods of increase in the taper angle of the load. A detailed analysis requires also taking into account other effects, such as sediment supply, but since the flexural effects usually dominate, the use of these large-scale characteristics of basin evolution potentially allows to obtain reasonable estimates of the parameters listed above.

\section{Case histories}

\subsection{The Molasse basin}

The ca. $600 \mathrm{~km}$ long Tertiary Molasse basin (also called the North Alpine Foreland Basin) formed north of the Alps (Fig. 4) in Late Eocene to Middle Miocene times. The fill of the southern part of the basin was involved in the Alpine 


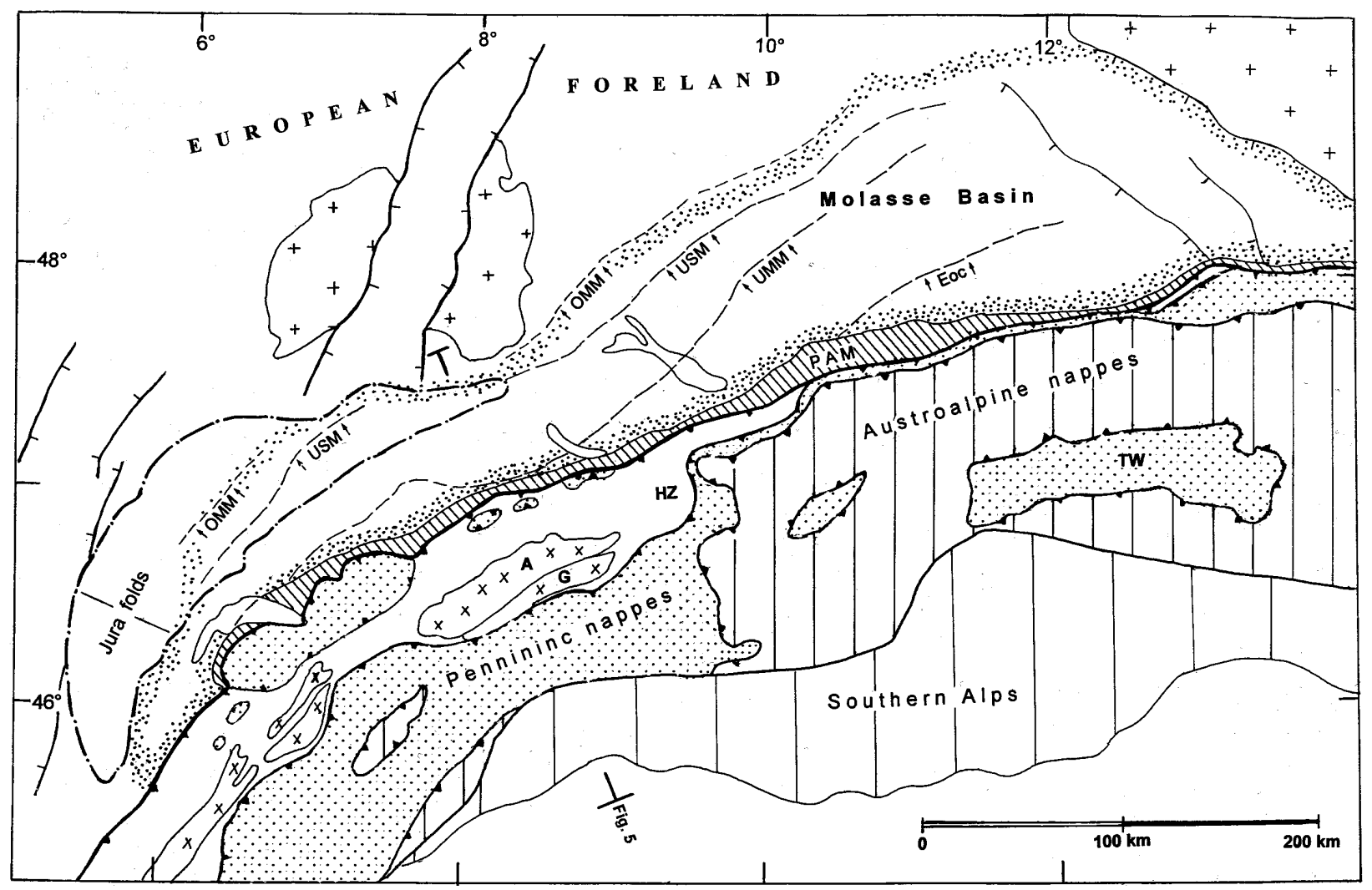

Fig. 4. The Molasse basin north of the Alps, showing the onlap of the different units of the basin fill on the foreland, after Bachmann et al. (1987), Homewood et al. (1986), Burkhard and Sommagura (1998), Ziegler et al. (1996).

deformation and is designated as the Subalpine Molasse. Farther north the basin fill remained essentially undeformed (Plateau Molasse). Here the relations between the histories of the foreland basin and the adjacent orogen are probably known in greater detail than anywhere else, so this area provides an opportunity to test the application of the approach outlined above.

The main features of the Molasse basin were summarized by Homewood et al. (1986), Pfiffner (1986), Bachmann et al. (1987), Sinclair et al. (1991), Roeder and Bachmann (1996), Lihou and Allen (1996), Schlunegger et al. (1997a) and Burkhard and Sommaruga (1998). These studies show that the Mesozoic shelf sediments of the foreland were eroded before being covered by the sediments filling the flexural low, which is interpreted as recording erosion of an exposed forebulge that formed in front of the approaching Alpine orogenic wedge. Near the southern shelf edge (now within the Helvetic zone, Fig. 4) sedimentation began in the Middle Eocene, and it spread to more external areas in the Late Eocene, 40-38 Ma ago (time scale of Cande and Kent, 1992). Fast subsidence converted these areas into an underfilled basin where flysch accumulated, but soon after the beginning of the Oligocene shallow marine and continental sediments - the Molasse series proper - began to accumulate and onlapped over successively more external (northern) parts of the foreland. In most of the basin the
Molasse series is divided into four units, which are, from bottom to top (ages according to Schlunegger et al., 1997a): The Lower Marine Molasse (UMM, following the German usage) of Early Oligocene age; the Lower Freshwater Molasse (USM) of Late Oligocene to earliest Miocene age (ca 30 to ca. $20 \mathrm{Ma}$ ); the Upper Marine Molasse (OMM) of Early Miocene age (20-18 Ma); and the Upper Freshwater Molasse (OSM) of Middle to Late Miocene age (18 to ca. 13 Ma). The extent and thickness of these units were controlled primarily by down-flexing of the underlying European crust, though additional factors such as fluctuations of sea level and sediment supply also influenced the details of the section.

In the east (long $10^{\circ}-11^{\circ} \mathrm{E}$ ) the undeformed UMM covers a ca. $100 \mathrm{~km}$ wide belt, but originally it extended $>30 \mathrm{~km}$ farther south. Farther west this unit is increasingly deformed (Fig. 4), but palinspastic restorations show that originally the undeformed part of the basin was not much narrower than in the east. During deposition of the overlying USM the foreland basin fill extended some $40 \mathrm{~km}$ further north while its southern margin was deformed. At any time, however, the undeformed part of the basin had a similar width as before, though somewhat narrowing westward (Homewood et al., 1986; Sinclair and Allen, 1992; Roeder and Bachmann, 1996; Burkhard and Sommaruga, 1998). The younger units (OMM and OSM) spread still further over the foreland, but their original extent is obscured by erosion that was espe- 
cially large in the west. Many authors related this history to the development of a flexure in front of the advancing Alpine orogenic wedge emphasizing various points of view (e.g. Homewood et al., 1986; Stockmal et al., 1987; Sinclair et al., 1991; Sinclair and Allen, 1992; Schlunegger et al.,1997a, b). Here we examine this basin from the point of view outlined above.

As the history of the Molasse Basin records the advance over the foreland of a flexure whose width varies from 60 $80 \mathrm{~km}$ to about $100 \mathrm{~km}$ and somewhat more in the east, we infer from Fig. 2 that $\alpha \approx 50 \mathrm{~km}$ in the west and $\approx 75 \mathrm{~km}$ in the east. The onlap of the Molasse over the foreland since the end of the Eocene amounted to about $180 \mathrm{~km}$ in the central part of the basin (Fig. 4). This is interpreted to reflect a similar advance of the Alpine tectonic wedge. During the initial stages of basin evolution the edge of its fill advanced at a rate of $1 \mathrm{~cm} / \mathrm{y}$ or more, but the rate diminished to ca. $0.2 \mathrm{~cm} / \mathrm{y}$ during deposition of the USM, but the rate of onlap may have somewhat accelerated afterwards. Near the Alpine deformation front the basin fill reached a thickness of $3.5-4 \mathrm{~km}$ and $5 \mathrm{~km}$ to $>6 \mathrm{~km}$ at the end of deposition of the UMM and USM, respectively (Pfiffner, 1986). This indicates that the adjacent wedge had a taper angle of about $10^{\circ}$ and even reached $>13^{\circ}$ by the end of deposition of the USM (if it was ca. $150 \mathrm{~km}$ wide, cf. Fig. 2). An increase in the taper angle during deposition of the USM is indicated by the considerable thickness of this unit compared with the underlying basin fill, even though the USM was deposited while the rate of onlap of the basin edge over the foreland slowed down. Increased sediment supply that maintained the basin floor above sea level during that time would augment the onlap of the basin fill over the foreland, adding to the effect of the advance of the tectonic load, rather than slow it down. On the other hand, continuing subsidence is indicated by the fact that eventually the USM was lowered enough to be covered by the sea in which the OMM formed. Such behavior - continuing substantial subsidence while the load tip does not advance much - is expected when an increase in the taper angle of the load is the main cause of basin subsidence. Continuing subsidence of the basin during deposition of the OMM and OSM, and the thickness of the basin fill near the front of deformation $-4-5 \mathrm{~km}$ - suggest that during this period the taper angle of the load did not change much, though it may have eventually decreased.

To test to what extent these inferences compare with the data on the development of the adjacent tectonic wedge we examine the well-studied traverse across the central Alps (Schmid et al., 1996; Ziegler et al., 1996) next to the middle portion of the basin (Figs. 4, 5). We focus on the advance of the tectonic load and on changes in its taper angle - the most important features that are constrained by the record of the foreland basin.

Schmid et al. (1996) estimated that along this traverse plate convergence amounted to ca. $300 \mathrm{~km}$ since some $50 \mathrm{Ma}$ ago, and to ca. $150 \mathrm{~km}$ since $40 \mathrm{Ma}$. About $70 \mathrm{~km}$ of the latter were accommodated by backthrusting along the rear side of the Alpine tectonic wedge (on the Insubric Line) and by shor- tening in the southern Alps. This leaves ca. $80 \mathrm{~km}$ for the coeval shortening of the Alpine wedge and its advance over the European foreland, whereas the onlap of the Molasse basin fill on the foreland in the same period was ca. $180 \mathrm{~km}$ (see above). This difference calls for reexamining the above estimate and suggests that it may be too low, because otherwise it would be very difficult to explain the advance of the basin over the foreland as a result of flexure.

The data along this traverse also allow to examine the inferences regarding the taper angle of the Alpine wedge. Two stages need to be distinguished. In the early stage the wedge developed by stacking and folding of the Penninic nappes and by emplacement of exhumed units that experienced very high-pressure metamorphism. Along this traverse the Adula nappe (Fig. 5) was subducted to a depth of $\geq 120 \mathrm{~km}$ ( $\mathrm{p} \geq 35 \mathrm{kbar}$ ) 43-40 Ma ago, but it was exhumed to depths of $40 \mathrm{~km}$ and less by 35-33 Ma ago (Gebauer, 1996), i.e. in the lastest Eocene (time scale of Cande and Kent, 1992). Such reshuffling of large units does not allow estimating the taper angle at that stage, i.e. before and during initiation of the foreland basin.

However, by $32 \mathrm{Ma}$ to $27 \mathrm{Ma}$ ago the thermal regime led to development of metamorphic isograds that cut across the boundaries of the Penninic nappes (Frey et al., 1980; Vance and O'Nions, 1992). This indicates thermal equilibration of adjacent nappes and therefore the end of significant motions between the various parts of the Alpine tectonic wedge, allowing to estimate its taper angle. At that time (end of deposition of the UMM) the presently exposed rocks in the southern part of the wedge were at pressures of $6.5 \pm 1.5 \mathrm{kbar}$ to $8.5 \pm 1.5$ (ibid.), i.e. at depths of $25-30 \mathrm{~km}$. Combined with the seismically determined position of the base of the Penninic nappes (Fig. 5), this shows that the internal part of the wedge was $30-40 \mathrm{~km}$ thick. The width of the wedge is estimated as ca. $150 \mathrm{~km}$, allowing for subsequent shortening by backfolding in its southern part and for erosion of its frontal part (today the remaining part is ca. $100 \mathrm{~km}$ wide). This implies a taper angle of $11^{\circ}-15^{\circ}$ that is broadly similar to the estimate obtained above. The taper would be somewhat smaller if the shortening of the southern part of the wedge were underestimated (as suggested by Schmid et al., 1996).

For the following period, i.e. the time of deposition of the USM, OMM and OSM, the onlap of the Molasse basin over the foreland indicates that the advance of the Alpine tectonic wedge slowed down, in accord with the history of Alpine deformation presented by Schmid et al. (1996). The record of the foreland basin also implies an increase in the taper angle during deposition of the USM, as discussed above. Such a change of the orogenic wedge was already inferred from different considerations (Sinclair et al., 1991; Sinclair and Allen, 1992; Schlunegger et al., 1997b), which supports the validity of our analysis. It is noteworthy that the inferred thickening of the wedge took place while it was being strongly eroded (Sinclair and Allen, 1992; Schlunegger et al., 1997b), which would tend to reduce its taper angle. This shows that other processes more than compensated for the erosion by modifying the lower parts and/or interior of 


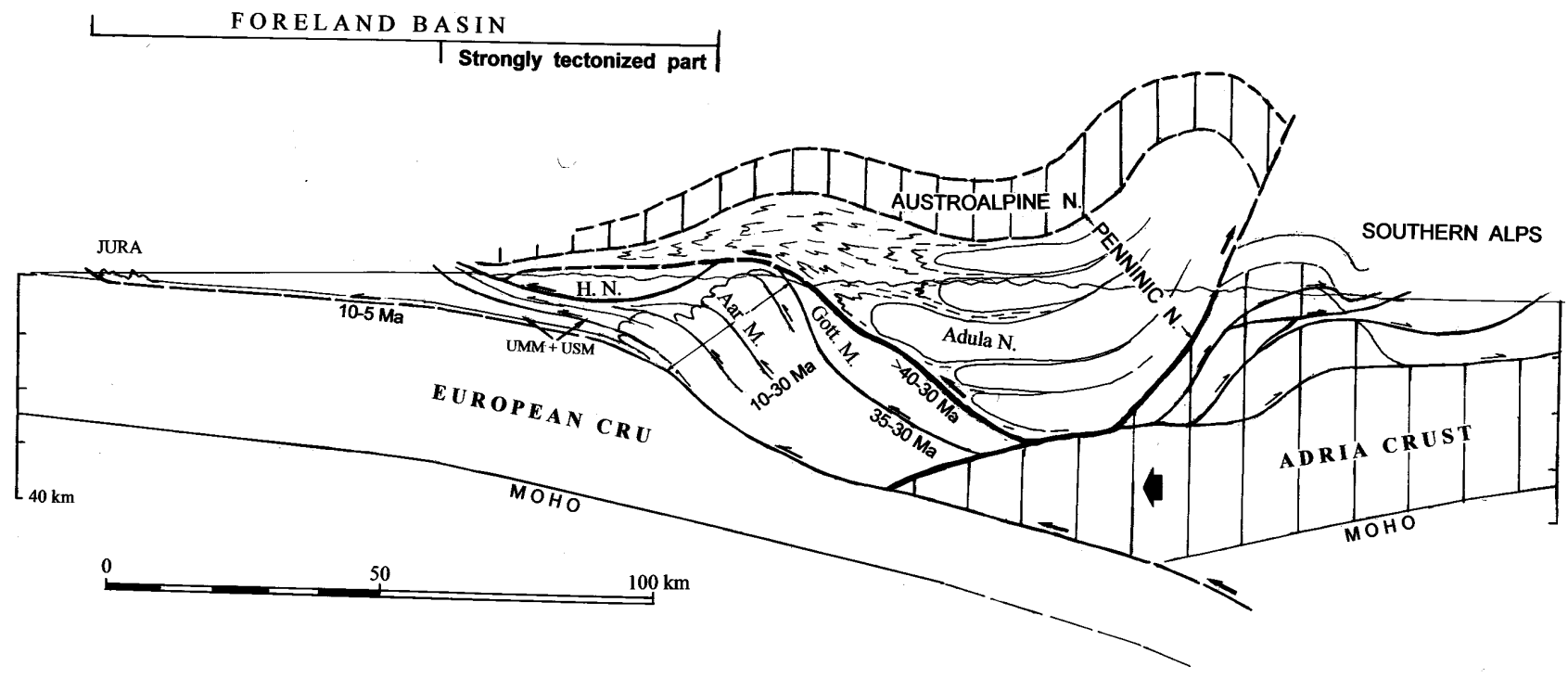

Fig. 5. Cross section along the traverse through the Molasse basin and central Alps discussed in text, shows ages of important motions on the major thrusts (after Pfiffner, 1986; Schmid et al., 1996; Schmid and Kissling, 2000). Location shown in Fig 4. See text for discussion.

the wedge.

One mechanism that could contribute to maintaining the volume of the wedge was underplating by incorporation of slices derived from successively more external parts of the foreland. This is evidenced by the younging of the major thrust movements toward the exterior of the orogen (Milnes and Pfiffner, 1977; Pfiffner, 1986: Schmidt et al., 1996) as shown in Fig. 5. Thus, the thrust beneath the Helvetic nappes formed at the end of the Eocene, while that beneath the northern flank of the underlying Gotthard massif formed in the Early Oligocene. Since late-Oligocene times the still more external Aar massif and adjacent parts of the Molasse basin were thrust northward, while in mid-Miocene times the entire Aar massif was thrust over the foreland. These units became incorporated into the tectonic wedge and formed a stack of thrust slices that extend to a considerable depth beneath its frontal part. A similar history is also recognized farther west where the external massifs and the adjacent parts of the Molasse basin became successively incorporated into the orogenic wedge (Homewood et al., 1986; Burkhard and Sommaruga, 1998). Geometric compatibility requires that the northward displacement of these external units was accompanied by continuing advance of the entire orogenic wedge south of them as a piggy-back stack of nappes. This, in turn, requires that a thrust or shear zone remained active under its base. The newly formed thrusts and shear zones in the external part of the wedge must have joined this deep movement zone beneath its internal part. This history raises the possibility that the thickening of the orogenic wedge resulting from underplating that outweighed its erosion.

Another mechanism that modified the Alpine wedge from below was indentation, i.e. emplacement of material from the rear concurrently with its continuing advance. Roure et al. (1996) suggested that a wedge of slices derived from the Eu- ropean lower crust was pushed beneath the Alpine wedge in front of the Adria plate. Schmid and Kissling (2000) concluded that along the studied traverse the frontal part of the Adria plate was pushed in between the Alpine tectonic wedge and the underlying European crust (Fig. 5), while farther west a slice of the European lower crust was pushed in front of the Adria plate. Emplacement of such bodies augments the orogenic wedge on top of the subducted European crust and will enhance the flexure of the foreland, being equivalent to an increase in the taper angle of the load. The role of such loading and its contribution to the flexure of the foreland may well be generally more important than recognized hitherto. For completeness, it should be mentioned that the Alpine tectonic wedge continued to advance northward also after deposition of the OSM. Then the entire Molasse basin west of long. $8.5^{\circ} \mathrm{E}$ moved northward up to ca. $30 \mathrm{~km}$ over a newly formed detachment which produced the Jura fold bundle in the Late Miocene and Pliocene, though the depth of the detachment is still controversial (Ziegler et al., 1996).

It would be desirable to extend the analysis also east of the examined traverse where the record of the basin would lead to similar inferences regarding the orogenic load. However, the widespread cover of the Austro-Alpine nappe pile (Fig. 4) hides most of the underlying tectonic wedge, so at present its history is not known in sufficient detail to test the inferences from the foreland basin.

In summary, the foregoing considerations show that the implications of the Molasse basin for the development of the adjacent orogenic wedge are broadly compatible with the record of the Alps. This supports the use of the geometry of other foreland basins to constrain temporal variations of large-scale features of the causative tectonic wedges. 


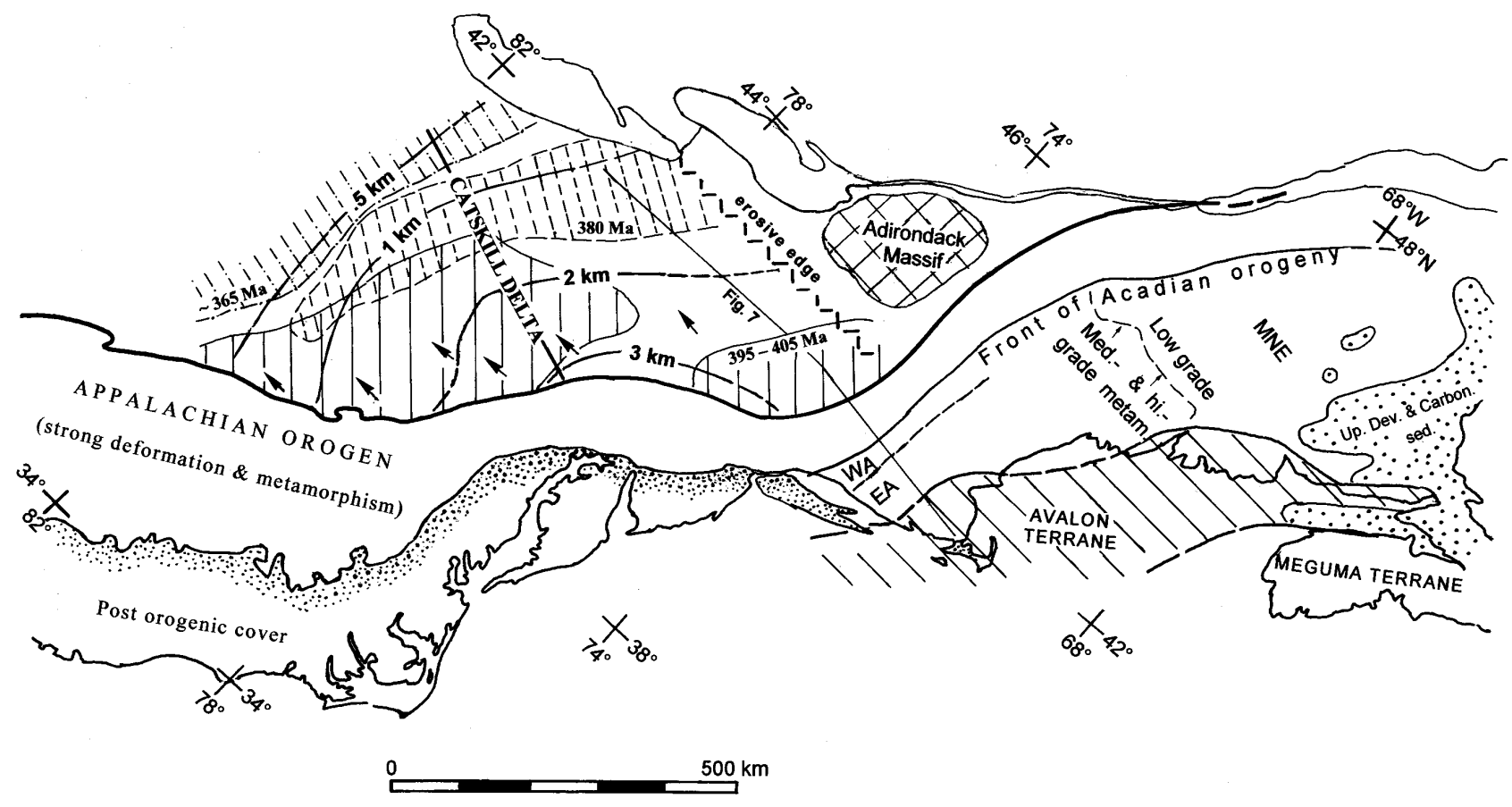

Fig. 6. The Devonian foreland basin (Catskill Delta) of the central Appalachians. Showing migration of the distal delta facies and the metamorphic zones of the Acadian orogen in New England (after Williams and Hatcher, 1983; Faill, 1985; Robinson et al., 1998). Contours: thickness of the Devonian clastic wedge (Catskill Delta). MNE - Medial New England terrain. Patterns with age indications: successive positions of distal black shale facies of the Catskill Delta, after Ettenson, 1985. WA and EA - the Western and Eastern Acadian metmaorphic zones, after Armstrong et al., 1992.

\subsection{Devonian foreland basin of the Appalachians}

The development of the Appalachians was accompanied by the formation of a succession of foreland basins along the edge of Laurentia that are interpreted as flexural features (Quinlan and Beaumont, 1984; Tankard, 1986; Thomas and Schenk, 1988). Here we examine the record of the Devonian foreland basin next to the central Appalachians (Fig. 6) from the point of view presented above and explore its implications for the adjacent orogen.

This foreland basin formed during the Acadian orogenic phase (410-405 Ma to 360-350 Ma ago: Devonian time scale of Tucker et al., 1998) that is well expressed in New England and in more northern parts of the Appalachians (Fig. 6; Williams and Hatcher, 1983; Osberg et al., 1989; Tremblay and Pinet, 1994; Pinet and Tremblay, 1995; Robinson et al., 1998). The clastic fill of this foreland basin, known as the Catskill Delta (Fig. 6), extends some $500 \mathrm{~km}$ along the Appalachian orogen (lat. $38^{\circ}$ to $43^{\circ} \mathrm{N}$ ). Its northern edge is eroded, but there is no evidence that it extended much farther to the north $(<200 \mathrm{~km}$ ?), while its southeastern eroded edge extends along the front of the strong orogenic deformation. The development of this basin was summarized by Dennison (1985), Ettensohn (1985), and Faill (1985, 1997) who emphasized its relation with the Acadian deformation in the adjoining Appalachian orogen. These studies show that the influx of clastics from the east, i.e. from the Appalachian mountain chain, began in the Emsian and contin- ued until the earliest Carboniferous. However, most of the clastic fill of the basin accumulated during the Middle Devonian (ca. 395-383 Ma) and especially during the Late Devonian (383-362 Ma ago). Close to the orogen large parts of the basin fill consist of continental beds, but further away from the orogen the entire clastic basin fill consists of marine sediments. Towards the west and southwest these clastics thin and pass laterally into the marine cover of the interior of the Laurentian platform. Local unconformities exist, but they do not define a forebulge that migrated to successively more external positions during basin development. The subsidence of the Laurentian platform and consequent deposition of its cover began in the Cambrian and continued into the Devonian, apparently independently of the foreland basin formation, which prevented the forebulge from rising enough to be significantly eroded. Therefore it is not possible to define onlap relations along the edge of the foreland basin, but the thickness variations of the basin fill and the westward migration of the main facies belts - distal delta, proximal delta, alluvial fan and redbeds - reflect the overall migration of the flexure. In particular, basinal shales along the western side of the clastic buildout shifted westward by $200-250 \mathrm{~km}$ from ca. $400 \mathrm{Ma}$ ago to ca. $375 \mathrm{Ma}$ ago, and an additional 100$150 \mathrm{~km}$ in the next $15 \mathrm{Ma}$ (Ettensohn, 1985; Fig. 6). This is interpreted as recording the down-flexing of successively more external parts of the foreland, and as discussed above, it is considered to record a comparable advance of the Acadian orogenic wedge over Laurentia, though enhanced sediment 
supply from the east probably also contributed to shifting of the facies belts.

The Catskill delta is exceptionally wide, $\geq 300 \mathrm{~km}$, because its fill extends over the forebulge. The down-flexed area was probably narrower, perhaps ca. $200 \mathrm{~km}$ wide, suggesting that $\alpha \approx 120-130 \mathrm{~km}$. The total down-flexing at the end of the Devonian exceeded $3.5 \mathrm{~km}$ (top of sequence is eroded), which implies that the causative load had a taper angle of $\geq 6^{\circ}-7^{\circ}$, but this is a very approximate estimate. The continuing subsidence of the flexural basin, which may have even accelerated in the Late Devonian, suggests that the taper angle of the wedge did not change much or may have even somewhat increased as it advanced over the foreland, but details cannot be resolved. These values, though not very precise and in need of further testing and refining, provide an estimate of what the size and displacement of the tectonic wedge should have been in order to produce the flexure recorded by the foreland basin.

To explore the implications of the above estimates for the adjacent orogen, we examine a traverse close to lat. $42^{\circ} \mathrm{N}$ through southern New England (Fig. 6). Here the Appalachians were shaped during several orogenic phases. In the Taconian phase, culminating 460-440 Ma ago, the Medial New England (Gander) terrane was accreted to Laurenia and both were strongly tectonized while an oceanic area that had existed between them was eliminated (Williams and Hatcher, 1983; Stanley and Ratcliffe, 1985; Pinet and Tremblay, 1995; Ratcliffe et al., 1998). Later the Acadian orogeny affected the Medial New England terrane together with its post-Taconian sedimentary-volcanic cover as well as more eastern terranes (Osberg et al., 1989; Tremblay and Pinet, 1994; Pinet and Tremblay, 1995; Robinson et al., 1998). Still later deformation took place during the Alleghanian phase. Along the studied traverse only the deeper part of the Acadian orogen, which experienced medium and high-grade metamorphism, is preserved. It is delimited on the west by a line of major thrusting, which separates it from a ca. $60 \mathrm{~km}$ wide zone in which only Taconian deformation and metamorphism are recorded (Fig. 6). The eastern part of the studied traverse crosses the Avalon terrane that was accreted to the Medial New England terrane during the Acadian orogeny. Seismic reflection studies show that the Taconian and Acadian structures form a wedge pushed westwards over Laurentian continental crust, and that in the subsurface the latter extends to a distance of some $150 \mathrm{~km}$ east of the Catskill Delta (Phinney and Roy-Chowdhury, 1989).

The above estimates of the displacement of the Acadian tectonic wedge and its taper angle allow constraining in broad outline the development of the adjacent orogen, as shown in cross-sections in Fig. 7. These cross-sections are highly simplified, being intended to depict merely the implications of the record of the foreland basin for the overall structure of the causative load. More detailed reconstructions are not warranted also because only approximate estimates of the advance and shape of the orogenic wedge could be obtained, and these should be further tested and improved in the future.
Along the studied traverse the preserved part of the Acadian orogen comprises two metamorphic zones (Armstrong et al., 1992) - Western and Eastern - that had different thermal histories (WA and EA in Figs 6, 7). In the Western Zone strong deformation dominated by westward tectonic transport and metamorphism at peak conditions of $\mathrm{p}=6-$ $8 \mathrm{kbar}$ (i.e. $22-29 \mathrm{~km}$ depth) and $\mathrm{T}=500^{\circ}-700^{\circ} \mathrm{C}$ took place ca. 400-395 Ma ago (late Emsian: Tucker et al., 1998) and somewhat later (Armstrong et al., 1992; Sevigny and Hanson, 1993; Lanzirotti and Hanson, 1995). The rocks near the present western border of this zone record $p=4-6 \mathrm{kbar}$ at least, i.e. depths of $15-22 \mathrm{~km}$ or more, and $\mathrm{T}=500^{\circ}-700^{\circ} \mathrm{C}$ (Hames et al., 1991). These age determinations show that the Acadian tectonic wedge was already strongly deformed and metamorphosed when clastics derived from the east were first transported into the foreland basin. The inferred migration of the tectonic wedge implies that then its tip was located some distance east of the Catskill Delta (Fig. 7). In a wedge having a taper angle of $8^{\circ}$ the rocks of the Western Zone, metamorphosed at a depth of 15-22 km (4-6 kbar), must have been located at least $105-155 \mathrm{~km}$ east of its tip (Fig. 7), and even further away if the taper was $6^{\circ}-7^{\circ}$. This implies that a wide frontal portion of the Acadian orogenic wedge has been destroyed, probably eroded.

In the Middle and Late Devonian the Western Zone cooled to temperatures of $\leq 500^{\circ}$ (i.e. lower than during peak metamorphism), and cooling to $\mathrm{T} \leq 300^{\circ} \mathrm{C}$ continued into earliest Carboniferous times (Sutter et al., 1985; Dietsch et al., 1987; Harrison et al., 1989; Hames et al., 1991). In particular, in the western part of this zone temperatures dropped to $500^{\circ} \mathrm{C}$ and less between $405-400 \mathrm{Ma}$ ago to $380-350 \mathrm{Ma}$ ago. These rocks are now thrust over rocks that record only Taconian metamorphism and cooled to $\mathrm{T} \leq 500^{\circ} \mathrm{C}$ already ca. $440 \mathrm{Ma}$ ago. Such an abrupt change in thermal history shows that substantial thrust motions juxtaposed these units late in the Devonian (or still later). This supports the above inference that the Acadian orogenic wedge moved a significant distance westward over the Laurentian platform in the Middle and Late Devonian, i.e. when most of the subsidence of the foreland basin took place and most of its fill accumulated. It is quite likely that then the Laurentian crust extended under a large portion of the Acadian wedge, which controlled its down-flexing. However, granites that invaded the Eastern Acadian metamorphic zone at that time have a non-Laurentian source (Sevigny and Hanson, 1993), which indicates that Laurentian crust did not extend that far to the east beneath this zone (Fig. 7). Thus, this part of the orogenic edifice may have contributed little to the flexure of the foreland.

The Middle and Late Devonian cooling of the Western Acadian Zone, i.e. while most of the foreland basin fill accumulated, indicates considerable unroofing of this portion of the orogenic wedge, most likely by erosion that supplied sediments to the adjacent basin. On the other hand, the record of the foreland basin suggests that during this period the frontal part of the tectonic wedge, which caused most of the flexure, maintained its taper angle. This requires that the unroofing 


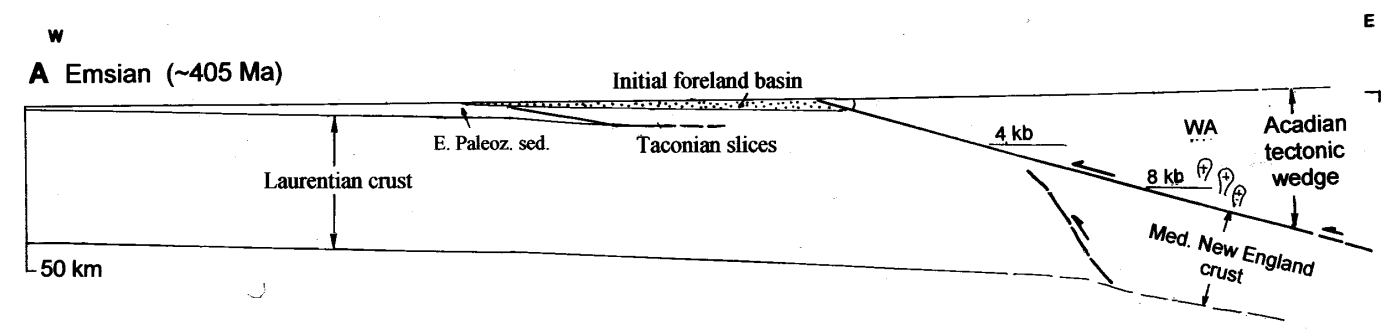

B End Devonian ( $365 \mathrm{Ma})$

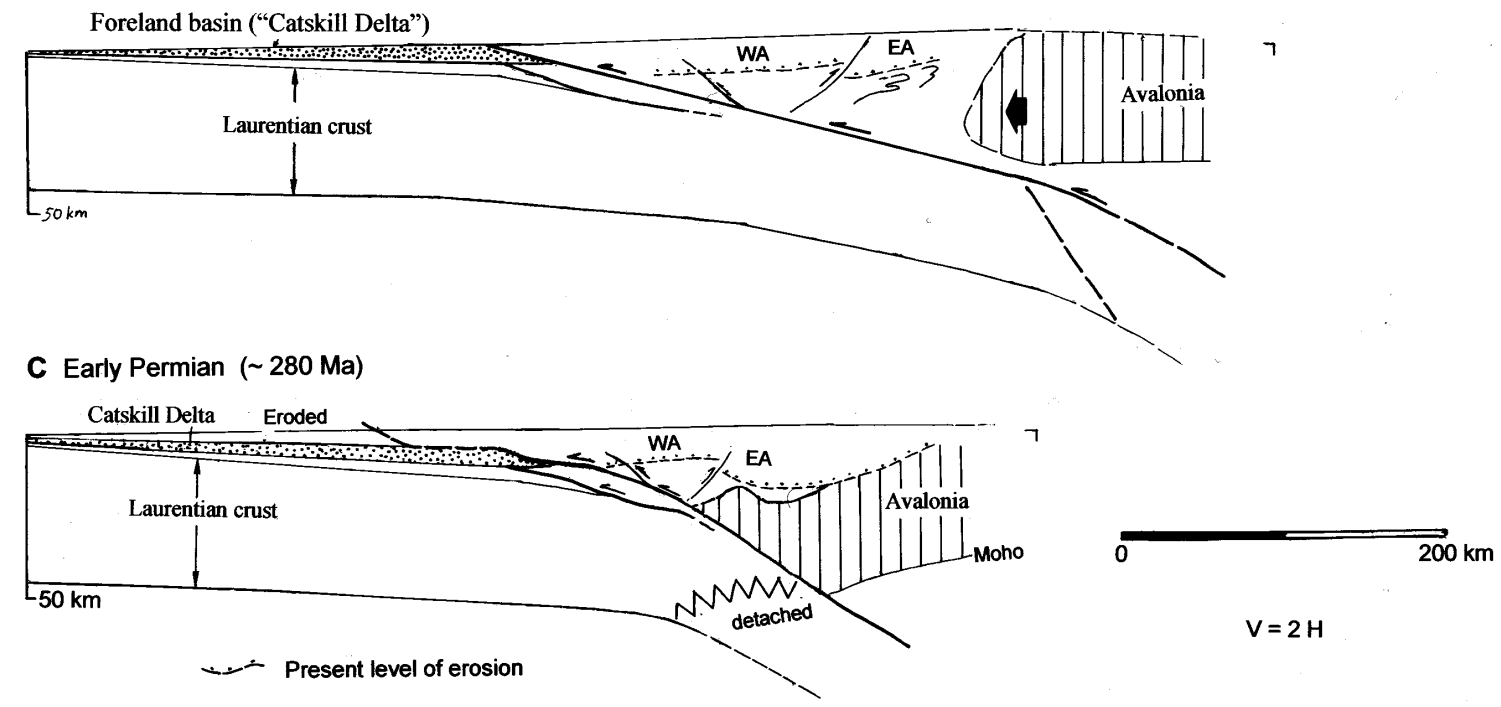

Fig. 7. Schematic cross-section showing possible development of the tectonic wedge through the Acadian foreland basin (Catskill Delta and southern New England. Location shown in Fig. 6. Tectonic history integrates the constraints derived from the foreland with data from the orogenic wedge. See text for discussion.

of the higher parts of the wedge be compensated by modification of its deeper levels. In part this probably resulted from the widespread continuing Acadian deformation that postdated peak metamorphism (Osberg et al., 1989; Robinson et al., 1998). Underplating of the frontal part of the wedge may have also taken place, but this possibility is difficult to evaluate.

Indentation of the Acadian orogenic wedge from the east could have also taken place. This is suggested by the widespread east-directed backfolding that was superposed on the early Acadian structures that formed by westward tectonic transport, especially in the Eastern Zone (Fig. 7; Osberg et al., 1989; Peterson and Robinson, 1993; Robinson et al., 1998). In the latter zone eastward tectonic transport produced large-scale backfolds and shear structures under highgrade metamorphic conditions $\left(\mathrm{T} \approx 700^{\circ} \mathrm{C}\right)$ in the Late Devonian and somewhat afterwards (370-350 Ma) - the NeoAcadian phase of Robinson et al. (1998). The backfolding can be interpreted as having been produced by a west-moving indenter that can be identified with the Avalon terrane. There is evidence showing that the Avalon terrane moved westward beneath the Eastern Acadian Zone, acting as an indenter, also in the Late Carboniferous, 300-285 Ma ago (Fig.7; Getty and Gromet, 1992; Wintsch et al., 1992; Moecher, 1999). At that time metamorphic conditions of $\mathrm{T}=600^{\circ}-650^{\circ} \mathrm{C}$ and $p=6.5 \pm 1 \mathrm{kbar}$ prevailed along the contact between these units, showing that here the overlying orogenic wedge was then $20-27 \mathrm{~km}$ thick. Thus it appears that the Avalon terrane acted as an indenter since its accretion to North America. As a result, it underlies the metamorphosed Early Paleozoic supra-crustals of the Eastern Zone (Fig. 7), which implies that the original pre-Acadian basement of these series must have been pushed below the indenting Avalon terrane and most likely was detached. Later, in the Early Permian (280 $265 \mathrm{Ma}$ ago) normal-sense motion along the contact between the Acadian wedge and the Avalon terrane took place (ibid.), but this only modified the earlier structural situation.

The southward extension of the Acadian wedge is recognizable on a seismic profile close to lat. $40.5^{\circ} \mathrm{N}$ (Phinney and Roy-Chowdhury, 1989), but farther south post-Taconian sediments or volcanics are not known, so Devonian tectonism is difficult to identify next to the southern part of the Catskill delta. However, the former existence of a substantial Acadian orogenic wedge next to it, extending as far south as lat. $38^{\circ} \mathrm{N}$, must be postulated if the foreland basin is to be explained as a result of flexure in front of a tectonic load. This is supported by the finding that the detrital micas in the southern part of Catskill foreland basin are overwhelmingly 
of Devonian age, indicating that an extensive source that was affected by Acadian metamorphism originally existed nearby (Aronson and Lewis, 1994). On the other hand, the absence of a Devonian foreland basin south of the lat. $37^{\circ} \mathrm{N}$ shows that either the Acadian tectonic wedge did not extend that far south or that it was situated more to the east with respect to Laurentia than farther north.

For completeness, it should be mentioned that the western portion of the Acadian wedge was further modified by postAcadian deformation. This is inferred from the evidence that the eastern half of the Catskill Delta was overlain by a $\geq 5 \mathrm{~km}$ thick overburden, which covered Carboniferous rocks south of the studied traverse but no longer exists (Sarwar and Friedman, 1995; Zhang and Davis, 1993). This overburden may have consisted of the Appalachian orogenic wedge or of sediments that accumulated in response to additional downflexing of the foreland. In either case an additional advance of the Applalachian tectonic wedge during the Alleghanian orogenic phase is indicated (Fig. 7).

In summary, the foregoing discussion shows how the record of a foreland basin can be used to constrain the development of an old orogenic wedge that was considerably modified by subsequent deformation and partly obliterated by extensive erosion. In such a situation the original taper angle and motions of the wedge would be difficult to extract from the present orogenic structure. The record of the foreland basin allows, however, to estimate in broad outline these features of the orogenic wedge. This information, when combined with available field observations, can be used as a framework for reconstructing the orogenic history, though our simplistic analysis certainly requires much further improvement and should be extended and integrated with the wealth of existing data that could not be discussed here.

\section{Discussion}

In the foregoing sections we examined how the record of foreland basins can be related to the history of the causative orogenic loads, based on the interpretation of foreland basins as flexural depressions in front of tectonic loads. This permits using simple models of flexure due to two-dimensional wedge-shaped loads to quantitatively relate the size and subsidence history of the basins to the advance and to the taper angles of the loads. These relations, in turn, allow to utilize the record of the basins to constrain in broad outline the development of the adjacent orogenic wedges. Integration of this input with information from the orogenic edifice itself can improve the understanding of the orogenic history. Detailed interpretations require more realistic and sophisticated models that incorporate other effects besides flexure, but the input required for such modeling may sometimes be difficult to obtain, e.g. in old and much eroded orogens or when later deformation modified the original structure. In such cases simple models such as those used here allow using the record of foreland basins in order to obtain useful constraints and significant insights into the history of orogenic wedges.
The extensively studied Molasse basin and the Alps allows testing this approach. We find that the inferences derived from the features of the foreland basin are broadly compatible with current interpretations of the Alps, though some questions arise such as the amount of advance of the load over the foreland. In part this may reflect inadequacies of the modeling, but we suspect that the differences point at the need for improved interpretations. The other example, the Appalachian Devonian foreland basin, illustrates a case when the advance and taper angle of the tectonic wedge cannot be readily inferred from the orogenic belt itself, as this was much deformed and extensively eroded after the formation of the foreland basin. In this case the record of the foreland basin may be the only information that can be used to constrain the large-scale features of the orogenic wedge during basin evolution. Integration of the inferences derived from the basin record with other data provides a framework in which the orogenic evolution can be examined, supplementing the insights gained from data about the Acadian orogen itself. This case illustrates the potential use of information from foreland basins.

It is noteworthy that in both cases much of the shaping of the foreland basins continued well after the initial assembly and the main deformation and metamorphism of the causative orogenic wedges. The late stages of basin development highlight some aspects of the advanced evolution and modification of the nearby orogenic wedges. One aspect is that the basin record shows that in these stages orogenic wedges maintain or even increase their taper angles while they are much eroded, which tends to reduce the wedges. Combined, these constraints call for modification of the deeper parts of the wedges that offsets the thinning of the wedges by erosion. This can be achieved by internal deformation, underplating and indentation of tectonic slices from the rear. This inference is confirmed by the exceptionally abundant information about the Alps and is compatible with the information about the Acadian orogen. The late stages of basin development also constrain the duration of tectonic activity affecting the adjacent orogenic wedges, because continuing basin accentuation requires coeval augmentation of the loading of the foreland. This, in turn, implies continuing advance of the orogenic wedges over thrusts or shear zones at their base and/or modification of their lower parts, e.g. by indentation or other processes. Such tectonic activity at depth may not be readily inferred from the coeval record of cooling, waning of deformation, and erosion that take place in the cores of the adjacent mountain belts. In well studied young or still active orogens other lines of evidence, besides the record of the adjacent basin, may provide much information about the very late tectonic activity. However, in old orogens the foreland basins may be the main source of evidence regarding the final phases of tectonic activity that affects primarily the deeper parts of orogenic edifices but is not well expressed in their shallower exposed parts.

In conclusion, the above considerations show that the record of foreland basins can provide important insights into the adjacent mountain belts that supplement other lines of 
evidence regarding the structure and evolution of orogenic belts. Simple mechanical models of flexure due to twodimensional loads reveal quantitative relations that allow to use large-scale features of the basins to estimate and constrain the advance and the taper angle of the adjacent tectonic wedge. This can be particularly useful when the development and extent of orogenic wedges during basin formation is difficult to reconstruct because of subsequent erosion and deformation. The advanced stages of the basin history can also help to constrain the final stages of orogenic development because at that stage tectonic activity mostly continues at the deeper levels of orogenic wedges and does not affect much their eroded shallow parts. Thus the record of foreland basins provides a perspective on the orogenic evolution that supplements the data provided by the tectonic wedges themselves. Integration of the data from both the foreland and the interior of the orogen can, therefore, help to obtain a complete understanding of mountain belt evolution.

\section{Appendix : Flexure produced by a distributed 2-D load}

We develop here a method of modeling the flexure that a 2$\mathrm{D}$ distributed load of arbitrary cross-section produces on a thin semi-infinite elastic plate that floats on a fluid substratum. When the plate is not subject to horizontal stresses, then a load that is uniform perpendicular to the $x$ coordinate (Fig. 1) produces a deflection $w$, positive downward, that is described by the well known differential equation (Hetenyi, 1946; Nadai, 1963; Turcotte and Schubert, 1982)

$D \frac{d^{4} w}{d x^{4}}+\rho g w=q(x)$

where $\mathrm{D}=\mathrm{Eh}^{3} / 12\left(1-v^{2}\right)$ is the flexural rigidity ( $E$ is Young's modulus, $h$ is the effective thickness of the elastic plate, $v$ is Poisson's ratio), and is constant (otherwise terms including its derivatives will be present). The second term expresses the buoyancy arising because of the deflection of the plate ( $\rho$ is the density of the mantle and $g$ is the acceleration of gravity). The term on the right $-q(x)-$ expresses the pressure due to all the loads that act on the plate except for the buoyancy.

We use standard methods to solve this equation for a concentrated line load of magnitude $V$ (per unit length perpendicular to the $x$ coordinate) placed on a semi-infinite plate $(0 \leq x \leq \infty)$, at a distance $x^{*}$ from the plate edge (Fig. 1), subject to the following boundary conditions: the plate edge, $x=0$, is free, and $w(x) \rightarrow \infty$ as $x \rightarrow \infty$. At $x^{*}$, under the concentrated load, the deflection, slope of the plate, and the bending moments are continuous, but there is a jump of magnitude $V$ in the vertical shear stress within the bent plate (Hetenyi, 1946). The values of $D$ and $\rho$ enter the solution through the single parameter $\alpha$, called the flexural parameter, which has units of length and is given by

$\alpha=\left[\frac{4 d}{\rho g}\right]^{1 / 4}$.
When $0 \leq x \leq x^{*}$, i.e. to the left of the load, the deflection $w_{l}\left(x, x^{*}\right)$ is given by

$$
\begin{gathered}
w_{l}\left(x, x^{*}\right)=\frac{V}{2 \alpha \rho g}\left[e^{\frac{x-x^{*}}{\alpha}}\left(\cos \frac{x-x^{*}}{\alpha}-\sin \frac{x-x^{*}}{\alpha}\right)+\right. \\
\left.e^{\frac{x+x^{*}}{\alpha}}\left(2 \cos \frac{x-x^{*}}{\alpha}+\cos \frac{x+x^{*}}{\alpha}-\sin \frac{x+x^{*}}{\alpha}\right)\right]
\end{gathered}
$$

When $x^{*} \leq x$ i.e. to the right of the load, the deflection $w_{r}\left(x, x^{*}\right)$ is given by

$$
\begin{gathered}
w_{r}\left(x, x^{*}\right)=\frac{V}{2 \alpha \rho g}\left[e^{-\frac{x-x^{*}}{\alpha}}\left(\cos \frac{x-x^{*}}{\alpha}+\sin \frac{x-x^{*}}{\alpha}\right)+\right. \\
\left.e^{\frac{-x+x^{*}}{\alpha}}\left(2 \cos \frac{x-x^{*}}{\alpha}+\cos \frac{x+x^{*}}{\alpha}-\sin \frac{x+x^{*}}{\alpha}\right)\right] \text { (A4) }
\end{gathered}
$$

When $x^{*}=0$ equation (A4) gives the deflection of a broken plate due to a load placed along the break (note that this case depicts two adjacent semi-infinite plates with free edges, while only half the total load affects each side). Taking $x-x^{*}$ as the distance from the load, and letting $x^{*} \rightarrow \infty$, then equation (A4) reduces to the expression for the deflection due to a line load placed on an infinite plate.

The deflection produced by a distributed load placed over the interval $0 \leq x^{*} \leq \mathrm{A}$ can be calculated, following Nadai (1963), by treating it as consisting of the sum of elementary loads $q\left(x^{*}\right) d x$. The total deflection at any place is the sum (integral) of the deflections due to the elementary loads given by equations (A3) and (A4) in which $V$ is replaced by $q\left(x^{*}\right)$. Thus, the deflection $W_{1}(x)$ under the load itself, i.e. when $0 \leq x \leq \mathrm{A}$, and the deflection $W_{2}(x)$ outside the load, i.e. when $\mathrm{A} \leq x$ are given, respectively, by

$$
\begin{aligned}
& W_{1}(x)=\int_{0}^{x} w_{r}\left(x, x^{*}\right) d x^{*}+\int_{x}^{A} w_{l}\left(x, x^{*}\right) d x^{*} \\
& W_{2}(x)=\int_{0}^{A} w_{r}\left(x, x^{*}\right) d x^{*}
\end{aligned}
$$

These integrals can be evaluated numerically for any given $q(x)$.

To complete the modeling, the effects of a vertical shear stress $V_{0}$ and bending moment $M_{0}$ applied at $x=0$, i.e. along the edge of the semi-infinite plate (Fig. 1), should also be incorporated into the solution. Since equation (A1) is linear, this is accomplished by adding to the solution given by (A5) and (A6) an extra deflection given by

$$
W(x)=\frac{2 e^{-\frac{x}{\alpha}}}{\rho g \alpha^{2}}\left[\left(M_{0}+\alpha V_{0}\right) \cos \frac{x}{\alpha}-M_{0} \sin \frac{x}{\alpha}\right]
$$

where $V_{0}$ and $M_{0}$ are given per unit length of the plate edge. This gives the effects of $V_{0}$ and $M_{0}$ acting on the plate edge when $q(x)=0$.

In applying these expressions to foreland basins the load is divided into two parts: the orogenic wedge and the fill of the basin, which usually will have different densities. For 
any given fill, equations (A5) and (A6) allow to calculate the level to which it extends (deflection of plate + thickness of load). The fill thickness cannot always be specified in advance because it also influences the flexure, but it can be constrained to extend to a prescribed level. The fill thickness can then be iteratively adjusted while evaluating $W_{1}(x)$ and $W_{2}(x)$, until it extends to the desired level.

Acknowledgements. We are very grateful to $\mathrm{M}$. Ford and F. Schlunegger for their comments that greatly improved this paper.

\section{References}

Armstrong, T. R., Tracy, R. J., and Hames, W. E.: Contrasting styles of Taconian, Eastern Acadian and Western Acadian metamorphism, central and western New England, Jour. Metam. Geol., 10, 415-426, 1992.

Aronson, J. L. and Lewis, T. L.: Ages of detrital white micas from Devonian-Pennsylvanian strata in the north central Appalachian Basin: Dominance of the Acaidan orogen as provenance, Jour. Geol., 102, 685-696, 1994.

Bachmann, G. H., Müller, H., and Weggen, K.: Evolution of the Molasse basin (Germany, Switzerland), Tectonophysics, 137, 77-92, 1987.

Beaumont, C.: Foreland basins, Geophys. Jour. Royal Astron Soc., 55, 471-497, 1981.

Burkhard, M. and Sommaruga, A.: Evolution of the western Swiss Molasse basin: structural relations with the Alps and the Jura belt, Geol. Soc. London. Spec. Publ., 134, 279-298, 1998.

Burov, E. B. and Diament, M.: The effective elastic thickness $\left(\mathrm{T}_{e}\right)$ of continental lithosphere. What does it really mean? Jour. Geophys. Res., 100, 3905-3927, 1995.

Cande, S. C. and Kent, D. V.: A new geomagnetic polarity time scale for the late Cretaceous and Cenozoic, Jour. Geophys. Res., 97, 13 917-13 951, 1992.

Cloetingh, S.: Intraplate stresses: A new element in basin analysis, in: Kleinspan, K. L. and Paola, C. (Eds): New perspectives in basin analysis, Springer, 205-230, 1988.

Cook, F. A. and Varsek, J. L.: Orogen-scale decollements, Rev. Geophys., 32, 37-60, 1994.

Dahlen, F. A.: Critical taper model of fold-and-thrust belts and accretionary wedges, Ann. Rev. Earth Sci., 18, 55-99, 1990.

Davis, D., Suppe, J., and Dahlen, F. A.: Mechanics of fold-andthrust belts and accretionary wedges, Jour. Geophys. Res., 88, 1153-1172, 1983.

DeCelles, P. G. and Giles, K. A.: Foreland basin systems, Basin Research, 8, 105-123, 1996.

Dennison, J. M.: Catskill Delta shallow marine strate, Geol. Soc. America, Spec. paper, 201, 91-106, 1985.

Dietsch, C. M. and Sutter, J.: Tectonic and metamorphic evolution of western Connecticut as interpreted from ${ }^{40} \mathrm{Ar} /{ }^{39} \mathrm{Ar}$ data, Geol. Soc. Amer. Abst. and Progr., 19(1), 11, 1987.

Ettensohn, F. R.: The Catskill Delta complex and the Acadian orogeny: a model. Geol. Soc. Amer. Spec. Paper, 201, 39-49, 1985.

Faill, R. T.: The Acadian orogeny and the Catskill Delta, Geol. Soc. Amer. Spec. Paper, 201, 15-37, 1985.

Faill, R. T.: A geologic history of the north-central Appalachians, part 2: The Appalachian basin from the Silurian through the Carboniferous, Am. Jour. Sci., 297, 729-761, 1997.
Flemings, P. B. and Jordan, T.: A synthetic stratigraphic model of foreland basin development, Jour. Geophys. Res., 94, 38513866, 1989.

Frey, M., Bucher, K., Frank, E., and Mullis, J.: Alpine metamorphism along the geotraverse Basel-Chiasso - a review, Eclog. Geol. Helv., 73, 527-546, 1980.

Garfunkel, Z. and Greiling, R. O.: Influence of the geometry of orogenic loads on foreland basins: Preliminary results, Z. Dt. Geol. Ges., 147, 415-425, 1996.

Getty, S. R. and Gromet, L. P.: Evidence for extension at the Willimantic dome, Connecticut: implications for the Late Paleozoic tectonic evolution of the New England Appalachians, Am. Jour. Sci., 292, 398-420, 1992.

Gebauer, D.: A P-T-t path for an (ultra?-) high pressure ultramafic/mafic rock- association and its felsic country-rocks based on SHRIMP-dating of magmatic and metamorphic zircon domains. Example: Alpe Arami (Central Swiss Alps), AGU Geophys. Mon., 95, 307-329, 1996.

Hames, W. E., Tracy, R. J., Ratcliffe, N. M., and Sutter, J. F.: Petrologic, structural and geochronologic characteristics of the Acadian metamorphic overprint on the Taconide zone in part of southwestern New England, Am. Jour. Sci., 291, 887-913, 1991.

Harrison, T. M. and Spear, F. S.: Geochronologic studies in central New England II: Post-Acadian hinged and differential uplift, Geology, 17, 185-189, 1989.

Hauk, M. L., Nelson, K. D., Brown, L. D., Zhao, W., and Ross, A. R.: Crustal structure of the Himalayan orogen at $\sim 90^{\circ}$ east longitude from project INDEPTH deep reflection profiles, Tectonics, 17, 481-500, 1998.

Hetenyi, M.: Beams on elastic foundation, Univ. Michigan Press, Ann Arbor, 225p, 1946.

Homewood, P., Allen, P. A., and Williams, G. D.: Dynamics of the Molasse basin of western Switzerland, Int. Assoc. Sedimentol. Spec. Publ., 8, 199-217, 1986.

Jordan, T. E.: Thrust loads and foreland basin evolution, Cretaceous, western United States, Amer. Assoc. Petrol. Geol. Bull., 65, 2506-2520, 1981.

Jordan, T. E. and Flemings, P. B.: Large-scale stratigraphic architecture, eustatic variations, and unsteady tectonism: A theroetical approach, Jour. Geophys. Res., 96, 6681-6699, 1991.

Karner, G. D. and Watts, A. B.: Gravity anomalies and flexure of lithosphere at mountain ranges, Jour. Geophys. Res., 88, $10449-$ $10477,1983$.

Lanzirotti, A. and Hanson, G. N.: U-Pb dating of major and accessory minerals formed during metamorphism and deformation of metapelites, Geochim. Cosmochim. Acta, 59, 2513-2526, 1995.

Lihou, J. C. and Allen, P. A.: Importance of inherited rift margin structures in the early North Alpine Foreland Basin, Switzerland, Basin Research, 8, 425-442, 1996.

Lyon-Caen, H. and Molnar, P.: Gravity anomalies, flexure of the Indian plate, and the structure, support and evolution of the Himalaya and Ganga Basin, Tectonics, 4, 513-538, 1985.

Milnes, A. G. and Pfiffner, O. A.: Structural development of the Infrahelvetic complex, eastern Switzerland, Eclog. Geol. Helv., 70, 83-95, 1977.

Moecher, D. P.: The distribution, style and intensity of Alleghanian metamorphism in south-central New England: Petrological evidence from the Pelham and Willimantic domes, Jour. Geol., 107, 449-471, 1999.

Nadai, A.: Theory of flow and fracture of solids, V. II, McGrawHill, 705p, 1963.

Osberg, P. H., Tull, J. F., Hon, R., and Butler, J. R.: The Acadian 
Orogeny, in: Hatcher, R. D., Jr., Thomas, W. A., and Viele, G. W. (Eds.): The Appalachian-Ouachita Orogen in the United States: The Geology of North America, v. F-2, Geol. Soc. America, 179232, 1989.

Peterson, V. L. and Robinson, P.: Progressive evolution from uplift to orogen-parallel transport in a late-Acadian upper amphiboliteto granulite-facies shear zone, south central Massachusetts, Tectonics ,12, 550-567, 1993.

Pfiffner, A. O.: Evolution of the north Alpine foreland basin in the Central Alps, Int. Assoc. Sedimentol. Spec. Publ., 8, 219-228, 1986.

Phinney, R. A. and Roy-Chowdhury, K.: Reflection sesimic studies of crustal structure in the eastern United States, in: Pakiser, L. C. and Mooney, W. D. (Eds.): Geophysical framework of the continental United States, Geol. Soc. America, Mem., 72, 613-653, 1989.

Pinet, N. and Tremblay, A.: Tectonic evolution of the QuebecMaine Appalachians; from oceanic spreading to obduction and collision in the northern Appalachians, Am. Jour. Sci., 295, 173200, 1995.

Price, R. A.: Large scale gravitational flow of supracrustal rocks, Southern Canadian Rockies, in: De Jong, K. A. and Scholten, K. (Eds.): Gravity and Tectonics, J. Wiley. New York, 491-502, 1973.

Quinlan, G. M. and Beaumont, C.: Appalachian thrusting, lithospheric flexure, and the Paleozoic stratigraphy of the eastern interior of North America, Canad. Jour. Earth Sci., 21, 973-996, 1984.

Ratcliffe, N. M., Hames, W. E., and Stanley, R. S.: Interpretation of ages of arc magmatism, metamorphism and collisional tectonis in the Taconian Orogen of western New England, Am. J. Sci., 791-797, 1998.

Robinson, P., Tucker, R. D., Bradley, D., Berry, H. N. IV, and Osberg, P. H.: Paleozoic orogens in New England, USA, Geologiska Foreninges I Stockholm Forhandlingar, 120, 119-148, 1998.

Roeder, D. and Bachmann, G.: Evolution, structure and petroleum geology of the German Molasse Basin, in: Ziegler, P. A. and Horvath, F. (Eds): Structure and prospects of Alpine basins and forelands, Peri-Tethys Mem. 2, Mus. Natn. D'Histoire Naturelle. Paris, 263-284, 1996.

Roure, F., Choukroune, P., and Polino, R.: Deep seismic reflection data and new insights on the bulk geometry of mountain ranges. Compt. Rend. Acad. Sci. Paris, 322, 345-359, 1996.

Sarwar, G. and Friedman, G. M.: Post-Devonian sediment cover over New York state. Lectures and Notes in Earth Sciences, Springer, 113p, 1995.

Schlunegger, E., Matter, A., Burbank, D. W., and Klaper, E. M.: Magneto-stratigraphic constraints on relationships between evolution of the central Swiss Molasse basin and Alpine orogenic events, Geol. Soc. Amer. Bull., 109, 225-241, 1997a.

Schlunegger, F., Jordan, T. E., and Klaper, E. M.: Controls of erosional denudation in the orogen on foreland basin evolution: the Oligocene central Swiss Molass Basin as an example, Tectonics, 16, 823-840, $1997 \mathrm{~b}$.

Schmid, S. M. and Kissling, E.: The arc of the western Alps in the light of geophysical data on deep crustal structure, Tectonics, 19, 62-85, 2000.

Schmid, S. M., Pfiffner, O. A., Froitzheim, N., Schönborn, G., and Kissling, E.: Geophysical-geological transect and tectonic evolution of the Swiss-Italian Alps, Tectonics, 15, 1036-1064,
1996.

Sevigny, J. H. and Hanson, G. N.: Orogenic evolution of the New England Appalachians of southwestern Connecticut, Geol. Soc. Amer., Bull. 105, 1591-1605, 1993.

Sinclair, H. D. and Allen, P. A.: Vertical versus horizontal motions in the alpine orogenic wedge: stratigraphic response in the foreland basin, Basin Research, 4, 215-232, 1992.

Sinclair, H. D., Coakley, B. J., Allen, P. A., and Watts, A. B.: Simulation of foreland basin stratigraphy using a diffusion model of mountain belt uplift and erosion: an example from the central Alps, Switzerland, Tectonics, 10, 599-620, 1991.

Stanley, R. S. and Ratcliffe, N. M.: Tectonic synthesis of Taconic Orogeny in western New England, Geol. Soc. Amer. Bull., 96, 1227-1250, 1985.

Stockmal, G., Beaumont, C., and Boutillier, R.: Geodynamic models of convergent margin tectonics: Transition from rifted margin to overthrust belt and consequences for foreland-basin development, Amer. Assoc. Petrol. Geol., 70, 181-190, 1986.

Stockmal, G. S. and Beaumont, C.: Geodynamic model of convergent margin tectonics: the southern Cordillera and the Swiss Alps. Canad. Soc. Petr. Geol. Mem., 12, 393-411, 1987.

Sutter, J. F., Ratcliffe, N. M., and Mukasa, S. R.: ${ }^{40} \mathrm{Ar} /{ }^{39} \mathrm{Ar}$ data bearing on the metamorphic and tectonic history of western New England, Geol. Soc. Amer. Bull., 96, 123-136, 1985.

Tankard, A. J.: On the depositional response to thrusting and lithospheric flexure: examples from the Appalachian and Rocky Mountain basins, Int. Assoc. Sedimentol. Spec. Publ., 8, 369392, 1986.

Thomas, W. A. and Schenk, P. E.: Late Paleozoic sedimentation along the Appalachian orogen. Geol. Soc. London Spec. Publ., 38, 515-530, 1988.

Tremblay, A. and Pinet, N.: Distribution and characteristics of Taconian and Acadian deformation, southern Quebec Appalachians, Geol. Soc. Amer. Bull., 106, 1172-1181, 1994.

Tucker, R. D., Bradley, D. C., Ver Straeten, C. A., Harris, A. G., Ebert, J. R., and McCutcheon, S. R.: New U-Pb zircon ages and the duration and division of Devonian time, Earth Planet, Sci. Letters, 158, 175-186, 1998.

Turcotte, D. L. and Schubert, G.: Geodynamics: Applications of continuum physics to geological problems, Wiley, 450p, 1982.

Vance, D. and O'Nions, R. K.: Prograde and retrograde thermal histories from the central Swiss Alps, Earth Planet. Sci. Lett., 114, 113-129, 1992.

Watts, A. B.: The effective thickness of the lithosphere and the evolution of foreland basins, Basin Research, 4, 169-178, 1992.

Williams, H. and Hatcher Jr., R. D.: Appalachian suspect terranes, Geol. Soc. Amer. Mem., 158, 33-53, 1983.

Wintsch, R. P., Sutter, J. F., Kunk, M. J., Aleinikoff, J. N., and Dorais, M. J.: Contrasting P-T-t paths: Thermochronological evidence for a Late Paleozoic final assembly of the Avalon Composite terrane in the New England Applalachians, Tectonics, 11, 672-689, 1992.

Zhang, E. and Davis, A.: Coalification patterns of the Pennsylvanian coal measures in the Appalachian foreland basin, western and south-central Pennsylvania, Geol. Soc. Amer. Bull., 105, 162-174, 1993.

Ziegler, P. A., Schmid, S. M., Pfiffner, A., and Schönborn, G.: Structure and evolution of the Central Alps and their northern and southern foreland basins, Peri-Tethys Memoir 2, Mém. Mus. Natn. D’Hist. Nat 170, Paris, 211-233, 1996. 